\title{
Analiza porównawcza sytuacji finansowej farm wiatrowych w wybranych krajach Unii Europejskiej w latach 2009-2017
}

\section{Comparative Analysis of Wind Farms Financial Situation in Selected Countries of the European Union in years 2009-2017}

\begin{abstract}
Synopsis. Celem publikacji była jest analiza porównawcza wybranych wskaźników sytuacji finansowej przedsiębiorstw, których główną działalnością jest generowanie energii wiatrowej i jej sprzedaż do sieci energetycznej. W publikacji porównano wybrane średnie wartości wskaźników finansowych dla następujących krajów Unii Europejskiej: Austria, Belgia, Bułgaria, Chorwacja, Czechy, Dania, Estonia, Finlandia, Francja, Grecja, Hiszpania, Holandia, Irlandia, Litwa, Łotwa, Niemcy, Polska, Portugalia, Rumunia, Słowacja, Słowenia, Szwecja, Węgry, Wielka Brytania, Włochy. Wnioskiem z badań jest wysoka rentowność farm wiatrowych w Austrii, Belgii, Portugalii i Wielkiej Brytanii, co pokrywa się z wysokimi cenami energii elektrycznej w tych krajach. Kraje z niższymi cenami energii odnotowały zwykle gorsze wyniki finansowe farm wiatrowych. Sa jednak od tej reguły wyjątki (farmy wiatrowe w Niemczech mimo wysokich cen energii elektrycznej nie uzyskiwały bardzo dobrych wyników finansowych).
\end{abstract}

Słowa kluczowe: farmy wiatrowe, źródła odnawialne energii, finanse przedsiębiorstw energetycznych

\begin{abstract}
The aim of the publication was a comparative analysis of selected indicators of the financial situation of enterprises whose main activity is the generation of wind energy and its sale to the power grid. The publication compared selected average values of financial ratios for the following European Union countries: Austria, Belgium, Bulgaria, Croatia, Czech Republic, Denmark, Estonia, Finland, France, Greece, Spain, the Netherlands, Ireland, Lithuania, Latvia, Germany, Poland, Portugal, Romania, Slovakia, Slovenia, Sweden, Hungary, Great Britain, Italy. The conclusion from the research is the authors observed high profitability of wind farms in Austria, Belgium, Portugal and the United Kingdom, which coincides with the high electricity prices in these countries. Countries with lower energy prices usually recorded worse financial results of wind farms. There are, however, exceptions to this rule (wind farms in Germany, despite high electricity prices, did not achieve very good financial results).
\end{abstract}

Keywords: wind farms, renewable resources, corporate finance

JEL Classification: G30, O13

\section{Wstęp}

Energetyka wiatrowa jest jedną $\mathrm{z}$ technologii pozwalających generować energię elektryczną bez emisji dwutlenku węgla, ani żadnych innych zanieczyszczeń do atmosfery, a także bez odpadów poprodukcyjnych. Do wad tej technologii należy uzależnienie od warunków pogodowych (od siły wiatru), kolizje z migrującymi ptakami, hałas, który może

${ }^{1}$ dr hab., prof. UEK, Katedra Finansów Przedsiębiorstw, Uniwersytet Ekonomiczny w Krakowie,

ul. Rakowicka 27, 31-510 Kraków, e-mail: wyrobekj@uek.krakow.pl; https://orcid.org/0000-0002-8536-0851 
być uciażliwy dla osób mieszkających blisko elektrowni wiatrowych (Gielnik, Rosicki, 2013). Jako jedno ze źródeł energii odnawialnej elektrownie wiatrowe są jednym $z$ narzędzi realizowania polityki Unii Europejskiej w zakresie celów związanych z energią i klimatem, w ramach których do 2020 roku w krajach członkowskich Unii Europejskiej udział energii pochodzącej ze źródeł odnawialnych w ogólnym zużyciu energii ma być nie niższy niż $20 \%$. Do roku 2030 udział ten ma wzrosnąć do co najmniej 27\%. Celem publikacji jest analiza porównawcza sytuacji finansowej wspomnianych elektrowni wiatrowych (farm wiatrowych) w wybranych krajach Unii Europejskiej, aby ocenić na ile energetyka wiatrowa jest obecnie (tzn. w latach 2009-2017) opłacalna pod względem finansowym.

\section{Przegląd wcześniejszych badań}

Badania nad opłacalnością finansową energetyki wiatrowej w stosunku do innych form energetyki (szczególnie węgla kamiennego) są zwykle realizowane poprzez obliczanie tzw. wskaźnika uśrednionego kosztu energii elektrycznej (ang. LCOE) obliczanego jako iloraz sumy kosztów w okresie trwania inwestycji (elektrowni) podzielonego przez ilość energii elektrycznej otrzymanej w tym czasie. Sumę kosztów elektrowni oblicza się jako zdyskontowaną sumę nakładów inwestycyjnych, kosztów operacyjnych i utrzymania elektrowni oraz energii jaka jest potrzebna do generowania nowej energii. Wartości reprezentujące wielkości energii generowane w kolejnych latach życia elektrowni także są dyskontowane tą samą stopą dyskontową co koszty i nakłady (Projected..., 2015). Zwykle do formuły LCOE dokładane są wartości dopłat oraz zielonych certyfikatów, które zmniejszają wartość kosztów w mianowniku, a także podatki i kary, jeżeli elektrownia będzie musiała je zapłacić (Bruck, Sandborn, Goudarzi, 2018).

$$
L C O E=\frac{\sum_{t=1}^{n} \frac{I_{t}+M_{t}+F_{t}-D_{t}-G_{t}+P_{t}}{(1+r)^{t}}}{\sum_{t=1}^{n} \frac{E_{t}}{(1+r)^{t}}}
$$

Gdzie: I(t) - nakłady inwestycyjne w roku t, $M(t)$ - koszty operacyjne i utrzymania elektrowni w roku t, $\mathrm{F}(\mathrm{t})$ - wydatki na energię potrzebną do funkcjonowania elektrowni w roku t, $\mathrm{D}(\mathrm{t})$ - dotacje $\mathrm{w}$ roku t, $\mathrm{G}(\mathrm{t})$ - cena certyfikatów emisyjnych w roku t, $\mathrm{P}(\mathrm{t})$ - kary za emisje $\mathrm{CO} 2, \mathrm{E}(\mathrm{t})$ energia elektryczna wygenerowana w roku $t, \mathrm{n}$ - oczekiwana liczba lat funkcjonowania elektrowni w latach.

Większość badań posługujących się, wskaźnikiem LCOE wykazuje niższe koszty energii wiatrowej niż energii uzyskiwanej z węgla kamiennego. Na przykład, w roku 2018 Franunhofer Institute for Solar Energy Systems ISE opublikował raport (Stromgestehungskosten ..., 2018), w którym oszacowano LCOE dla nowych elektrowni opartych na węglu kamiennym w przedziale cenowym 63-99 euro, dla energii wiatrowej onshore 40-82 euro, a offshore 75-138 euro (za $1 \mathrm{MWh}$ ). Ministerstwo Biznesu, Energii i Strategii Przemysłowej w Wielkiej Brytanii (BEIS - the Department for Business, Energy and Industrial Strategy) w 2015 roku podało z kolei następujące przedziały LCOE dla nowych elektrowni: koszt energii $\mathrm{z}$ węgla kamiennego powinien kształtować się w przedziale 124-171 GBP/MWh, a koszt energii wiatrowej onshore i offshore (odpowiednio) w przedziałach: 47-76 GBP (onshore) oraz 90-115 GBP/MWh (offshore). Z kolei agencja 
rządowa w USA Administracji Informacją Energetyczną (ang. EIA - Energy Information Administration) podała, że w 2022 roku nowe elektrownie na węgiel kamienny uzyskają LCOE na poziomie 103-196 USD/MWh, a wiatrowe onshore i offshore (odpowiednio): 43-75 USD/MWh (onshore) oraz 137-213 USD/MWh (offshore). Sugeruje to, że wyniki finansowe farm wiatrowych powinny być bardzo dobre, gdyż są w stanie produkować energię taniej od elektrowni węglowych.

Podane wartości dotyczą jednak elektrowni, które powstaną w przyszłości, a nie elektrowni, które już funkcjonuja. Za szacunek ceny energii dla obecnie funkcjonujących elektrowni węglowych (na węgiel kamienny) można przyjąc ceny z kontraktów na polskiej giełdzie towarowej na najbliższe 3 lata, które wahają się w przedziale 240-260 zł/MWh (z dostawą, dla poziomu cen za emisję $\mathrm{CO}_{2}$ do 20 euro/tonę) (Wieczerzak-Krusińska, 2018), jakkolwiek dla nowych elektrowni jest to cena znacznie wyższa (od 360 do $500 \mathrm{zł} /$ MWh) (Wieczerzak-Krusińska, 2018). Dla obecnie działających (kilku lub kilkunastoletnich) elektrowni wiatrowych onshore wydaje się to być przedział 346,9-415 zł/MWh (Mielcarek, 2014; Gnatowska, Wąs, 2015) (okres eksploatacji 20 lat, kurs euro/PLN $=4,20$ ). To z kolei rodzi pytanie jaka jest aktualna opłacalność farm wiatrowych i czy ich obecne wyniki finansowe zachęcają do realizowania kolejnych inwestycji. Dość istotnym elementem determinującym sytuację farm wiatrowych wydaje się być atmosfera polityczna wokół energii wiatrowej. W tabeli 1 przedstawiono ocenę nastawienia politycznego w krajach UE (za raportem Wind Energy in Europe: Outlook to 2020).

Tabela 1. Ocena nastawienia politycznego oraz stopnia realizacji celu OZE 2020 w wybranych krajach UE*, stan w roku 2018

Table 1. Political attitude and RES 2020 target realization level for selected EU countries, 2018

\begin{tabular}{|c|c|c|c|c|c|c|}
\hline Kraj & $\begin{array}{c}\text { Opis oczekiwanych decyzji politycznych w } \\
\text { zakresie energii wiatrowej }\end{array}$ & $\begin{array}{c}\text { Ocena } \\
\text { podejścia } \\
\text { politycznego }\end{array}$ & $\begin{array}{l}\text { Stopień } \\
\text { realizacji } \\
\text { OZE } 2020\end{array}$ & $\begin{array}{l}\text { Wzrost } \\
\text { roczny }\end{array}$ & $\begin{array}{c}\text { Moc } \\
\text { zainstalo- } \\
\text { wana } 2017 \\
\text { GW }\end{array}$ & $\begin{array}{c}\text { Nowa } \\
\text { moc w } \\
\text { latach } \\
2018- \\
2022\end{array}$ \\
\hline Austria & $\begin{array}{l}\text { Zmiany w ustawie o zielonej energii odblokują co } \\
\text { najmniej } 350 \mathrm{MW}\end{array}$ & neutralna & osiągnięty & $15 \%-35 \%$ & 2.8 & 1.1 \\
\hline Belgia & $\begin{array}{l}\text { Duży rozwój farm offshore, ale pewne ryzyko } \\
\text { zmian pogarszających sytuację istniejących farm }\end{array}$ & neutralna & $\begin{array}{l}\text { w trakcie } \\
\text { osiągania }\end{array}$ & $5 \%-15 \%$ & 2.8 & 2.5 \\
\hline Bułgaria & $\begin{array}{l}\text { Brak zachęt do budowania nowych farm } \\
\text { wiatrowych }\end{array}$ & negatywna & osiągnięty & $0 \%-5 \%$ & 0.7 & 0 \\
\hline Chorwacja & Rząd planuje generować $40-50 \%$ energii z wiatru & pozytywna & osiagnnięty & $5 \%-15 \%$ & 0.5 & 0.2 \\
\hline Czechy & $\begin{array}{l}\text { Farmy wiatrowe wymagają zgody Ministerstwa } \\
\text { Przemysłu }\end{array}$ & neutralna & osiągnięty & $0 \%-5 \%$ & 0.3 & 0 \\
\hline Dania & $\begin{array}{l}\text { Aktualna strategia kończy się w roku } 2018 \text {, nowa } \\
\text { strategia ma się pojawić dopiero za rok }\end{array}$ & neutralna & $\begin{array}{l}\text { w trakcie } \\
\text { osiągania }\end{array}$ & $5 \%-15 \%$ & 5.5 & 2.2 \\
\hline Estonia & $\begin{array}{l}\text { Zachęty do budowania kolejnych farm wiatrowych } \\
\text { pomimo osiągnięcia wartości wymaganych przez } \\
\text { UE }\end{array}$ & pozytywna & osiągnięty & $5 \%-15 \%$ & 0.3 & 0.19 \\
\hline Finlandia & $\begin{array}{l}\text { Strategia zachęt zakończy się po osiągnięciu limitu } \\
2500 \text { MVA }\end{array}$ & neutralna & osiągnięty & $5 \%-15 \%$ & 2.1 & 2.3 \\
\hline Francja & $\begin{array}{l}\text { Strategia rządu przewiduje dalszy rozwój farm } \\
\text { wiatrowych, } 15 \mathrm{GW} \text { do końca } 2018 \text { roku i } 25.8 \mathrm{GM} \\
\text { do końca } 2023 \text { roku }\end{array}$ & pozytywna & $\begin{array}{l}\text { daleko od } \\
\text { celu }\end{array}$ & $5 \%-15 \%$ & 13.8 & 11.7 \\
\hline Grecja & Przejście na system aukcji w roku 2018 & neutralna & $\begin{array}{l}\text { w trakcie } \\
\text { osiągania }\end{array}$ & $5 \%-15 \%$ & 2.6 & 1.3 \\
\hline Hiszpania & $\begin{array}{l}\text { Zakończenie aukcji po } 3 \text { aukcjach w 2016-2017, } \\
\text { warunki do inwestowania pozostają niekorzystne, }\end{array}$ & neutralna & $\begin{array}{l}\text { w trakcie } \\
\text { osiągania }\end{array}$ & $5 \%-15 \%$ & 23.2 & 7 \\
\hline
\end{tabular}




\begin{tabular}{|c|c|c|c|c|c|c|}
\hline Kraj & $\begin{array}{c}\text { Opis oczekiwanych decyzji politycznych w } \\
\text { zakresie energii wiatrowej }\end{array}$ & $\begin{array}{c}\text { Ocena } \\
\text { podejścia } \\
\text { politycznego }\end{array}$ & $\begin{array}{l}\text { Stopień } \\
\text { realizacji } \\
\text { OZE } 2020\end{array}$ & $\begin{array}{l}\text { Wzrost } \\
\text { roczny }\end{array}$ & $\begin{array}{l}\text { Moc } \\
\text { zainstalo- } \\
\text { wana } 2017 \\
\text { GW }\end{array}$ & $\begin{array}{l}\text { Nowa } \\
\text { moc w } \\
\text { latach } \\
2018- \\
2022\end{array}$ \\
\hline & prawo zniechęca do dalszych inwestycji & & & & & \\
\hline Holandia & $\begin{array}{l}\text { Farmy wiatrowe nadal dofinansowywane z budżetu } \\
\text { państwa aż do } 2020 \text { roku, ale raczej produkcja } \\
\text { energii nie osiagnie planowanego poziomu } 6 \mathrm{GW} \\
\text { onshore, dla farm offshore cel dla roku } 2023 \\
\text { wynosi } 4.5 \mathrm{GW}\end{array}$ & pozytywna & $\begin{array}{l}\text { daleko od } \\
\text { celu }\end{array}$ & $15 \%-35 \%$ & 4.3 & 5.7 \\
\hline Irlandia & $\begin{array}{l}\text { Trwa dyskusja polityczna dotycząca nowej strategii } \\
\text { i systemu zachęt }\end{array}$ & neutralna & $\begin{array}{l}\text { daleko od } \\
\text { celu }\end{array}$ & $5 \%-15 \%$ & 3.1 & 1.6 \\
\hline Litwa & $\begin{array}{l}\text { Rząd ustalił nowy cel strategiczny wynoszący } 30 \% \\
\text { konsumpcji energii z energii wiatrowej do roku } \\
2020\end{array}$ & neutralna & osiagnnięty & $5 \%-15 \%$ & 0 & 0.08 \\
\hline Lotwa & $\begin{array}{l}\text { Energia ze źródeł odnawialnych nie ma priorytetu, } \\
\text { ale kraj dąży do osiagnięcia udziału w konsumpcji } \\
\text { energii elektrycznej ze źródeł odnawialnych } \\
\text { wymaganego przez UE w } 2020 \text { roku }\end{array}$ & negatywna & $\begin{array}{l}\text { w trakcie } \\
\text { osiągania }\end{array}$ & $0 \%-5 \%$ & 0 & 0.06 \\
\hline Niemcy & $\begin{array}{l}\text { Pełne przejście na system aukcyjny dla energii ze } \\
\text { źródeł onshore i offshore, duża przewidywalność i } \\
\text { stabilność polityki }\end{array}$ & pozytywna & $\begin{array}{l}\text { w trakcie } \\
\text { osiągania }\end{array}$ & $5 \%-15 \%$ & 56.1 & 16.6 \\
\hline Polska & $\begin{array}{l}\text { Obecne uregulowania prawne ograniczają } \\
\text { powstawanie nowych farm, trwa dyskusja w } \\
\text { Parlamencie }\end{array}$ & negatywna & $\begin{array}{l}\text { daleko od } \\
\text { celu }\end{array}$ & $0 \%-5 \%$ & 5.8 & 0.5 \\
\hline Portugalia & $\begin{array}{l}\text { Brak zachęt do budowania nowych farm } \\
\text { wiatrowych }\end{array}$ & negatywna & $\begin{array}{l}\text { w trakcie } \\
\text { osiągania }\end{array}$ & $0 \%-5 \%$ & 5.3 & 0.3 \\
\hline Rumunia & $\begin{array}{l}\text { Brak zachęt do budowania nowych farm } \\
\text { wiatrowych }\end{array}$ & negatywna & osiągnięty & $0 \%-5 \%$ & 3 & 0.5 \\
\hline Słowacja & $\begin{array}{l}\text { Ostatnie zmiany ograniczają wsparcie państwa dla } \\
\text { farm wiatrowych - nałożono nowy podatek, } \\
\text { państwo będzie wybierało farmy, które są } \\
\text { wspierane }\end{array}$ & negatywna & osiągnięty & $0 \%-5 \%$ & 0 & 0 \\
\hline Słowenia & Skomplikowane procedury, podatki & neutralna & $\begin{array}{l}\text { daleko od } \\
\text { celu }\end{array}$ & $0 \%-5 \%$ & 0 & 0 \\
\hline Szwecja & $\begin{array}{l}\text { Cel dodatkowych } 18 \mathrm{TWh} \text { do roku } 2030 \text {, ale } \\
\text { oczekiwany wzrost energii z wiatru tylko na } \\
\text { początku tego okresu }\end{array}$ & neutralna & osiągnięty & $15 \%-35 \%$ & 6.7 & 4.7 \\
\hline Węgry & $\begin{array}{l}\text { Brak zachęt do budowania nowych farm } \\
\text { wiatrowych }\end{array}$ & negatywna & osiągnięty & $0 \%-5 \%$ & 0 & 0.3 \\
\hline $\begin{array}{l}\text { Wielka } \\
\text { Brytania }\end{array}$ & $\begin{array}{l}\text { Koniec systemu zielonych certyfikatów, ale energia } \\
\text { z farm offshore nadal jest wspierana za pomocą } \\
\text { systemu aukcji }\end{array}$ & pozytywna & $\begin{array}{l}\text { w trakcie } \\
\text { osiągania }\end{array}$ & $5 \%-15 \%$ & 18.9 & 7 \\
\hline Włochy & $\begin{array}{l}\text { System aukcyjny pozostaje, ale nie ma ogłoszeń o } \\
\text { nowych aukcjach }\end{array}$ & negatywna & osiągnięty & $5 \%-15 \%$ & 9.5 & 3 \\
\hline
\end{tabular}

Źródło: Wind Europe, Wind Energy in Europe: Outlook to 2020, Sept 2017, Bruksela, Belgia, Wind Energy in Europe Outlook to 2022, September 2018, Buksela, Belgia. Raporty pobrane z: http://windeurope.org.

Negatywne nastawienie polityczne obserwowane jest w krajach takich jak: Łotwa, Polska, Portugalia, Rumunia, Słowacja, Węgry, Włochy (tabela 1). Może to dodatkowo wpływać na słabsze wyniki finansowe farm wiatrowych w wymienionych krajach. 


\section{Metoda badawcza}

W celu oceny sytuacji finansowej farm wiatrowych w Unii Europejskiej zdecydowano zbadać następujące wskaźniki finansowe: wskaźnik rentowności kapitału własnego, wskaźnik płynności bieżącej oraz wskaźnik zadłużenia mierzony relacją zobowiązań odsetkowych do kapitału własnego. Wspomniane wskaźniki pokazują stopę zwrotu dla właścicieli przedsiębiorstwa, zdolność do terminowego regulowania zobowiązań bieżących oraz stopień zadłużenia jednostki.

Tabela 2. Liczba farm wiatrowych objętych badaniem w okresie 2009-2017, wybrane kraje Unii Europejskiej^ (liczby reprezentują liczbę dostępnych sprawozdań finansowych za dany rok)

Table 2. Number of available financial statements of wind farms in years 2009-2017, selected EU countries

\begin{tabular}{|c|c|c|c|c|c|c|c|c|c|c|c|}
\hline Kraj & Liczba & Liczba $>5$ turbin & 2017 & 2016 & 2015 & 2014 & 2013 & 2012 & 2011 & 2010 & 2009 \\
\hline Austria & 283 & 78 & 3 & 6 & 8 & 4 & 4 & 4 & 6 & 4 & 1 \\
\hline Belgia & 275 & $51 *$ & 42 & 41 & 40 & 35 & 31 & 27 & 25 & 24 & 17 \\
\hline Bułgaria & 77 & $30 *$ & 21 & 24 & 22 & 22 & 28 & 28 & 28 & 5 & 5 \\
\hline Chorwacja & 25 & 21 & 13 & 11 & 10 & 10 & 9 & 8 & 6 & 6 & 8 \\
\hline Czechy & 91 & $8^{*}$ & 5 & 9 & 9 & 8 & 9 & 9 & 9 & 9 & 7 \\
\hline Dania & 3258 & $106^{*}$ & 201 & 200 & 198 & 196 & 181 & 24 & 25 & 18 & 11 \\
\hline Estonia & 40 & $15^{*}$ & 11 & 14 & 14 & 9 & 8 & 10 & 11 & 11 & 12 \\
\hline Finlandia & 225 & $60 *$ & 48 & 54 & 70 & 57 & 51 & 28 & 22 & 15 & 13 \\
\hline Francja & 1394 & $577^{*}$ & 397 & 404 & 381 & 367 & 372 & 396 & 398 & 392 & 364 \\
\hline Grecja & 252 & 120 & 3 & 11 & 8 & 12 & 16 & 14 & 22 & 22 & 17 \\
\hline Hiszpania & 1157 & $838^{*}$ & 151 & 176 & 189 & 178 & 172 & 163 & 160 & 183 & 189 \\
\hline Holandia & 723 & 133 & 2 & 3 & 9 & 11 & 13 & 13 & 12 & 18 & 14 \\
\hline Irlandia & 276 & 115 & 13 & 22 & 22 & 14 & 8 & 7 & 7 & 7 & 11 \\
\hline Litwa & 74 & 11 & b.d. & 2 & 3 & 3 & 2 & b.d. & 1 & 1 & b.d. \\
\hline Łotwa & $34 *$ & $34 *$ & 33 & 31 & 33 & 33 & 34 & 33 & 31 & 26 & 3 \\
\hline Niemcy & 8528 & $1158 *$ & 28 & 131 & 147 & 129 & 136 & 121 & 109 & 78 & 70 \\
\hline Polska & 330 & $149 *$ & 32 & 105 & 178 & 172 & 165 & 128 & 114 & 91 & 57 \\
\hline Portugalia & 446 & $175^{*}$ & 85 & 90 & 88 & 90 & 82 & 74 & 87 & 92 & 92 \\
\hline Rumunia & 108 & $38 *$ & 6 & 39 & 38 & 42 & 43 & 49 & 52 & 47 & 32 \\
\hline Słowacja & 3 & 2 & 1 & 1 & 1 & 1 & 1 & 1 & 1 & b.d. & b.d. \\
\hline Słowenia & 4 & $4 *$ & 4 & 3 & 2 & 2 & 2 & 1 & 1 & 1 & b.d. \\
\hline Szwecja & 1100 & $148 *$ & 391 & 415 & 417 & 408 & 405 & 365 & 344 & 267 & 243 \\
\hline Węgry & $50 *$ & $50 *$ & 39 & 46 & 50 & 50 & 47 & 58 & 66 & 45 & 49 \\
\hline Wielka Brytania & 1088 & $422 *$ & 239 & 243 & 245 & 203 & 187 & 168 & 146 & 125 & 91 \\
\hline Włochy & 646 & $405^{*}$ & 243 & 302 & 316 & 311 & 283 & 291 & 286 & 289 & 241 \\
\hline Razem & - & & 2012 & 2384 & 2499 & 2368 & 2289 & 2020 & 1969 & 1776 & 1547 \\
\hline
\end{tabular}

Źródło: opracowanie własne na podstawie danych z bazy Orbis van der Vijk (^ pominięto kraje dla których nie posiadano danych). Liczba farm wiatrowych na podstawie: https://www.thewindpower.net/windfarms_list_en.php, (* przedział zaufania do max. 10\%).

Łączna liczebność próby badawczej wynosiła 4512 farm wiatrowych, a dane pozyskano z bazy Orbis. Ze względu na to, że farmy wiatrowe nie posiadały osobnego numeru klasyfikacji NACE, wyszukiwano je za pomocą nazwy, która musiała zawierać słowa „farma wiatrowa” lub ,energia wiatrowa” $w$ jednym $z$ języków kraju Unii Europejskiej, a także jako główną działalność NACE mieć wskazaną produkcję energii. 
Takie kryteria wyszukiwania ograniczyły liczbę podmiotów wykorzystanych do badania, ale dawały też pewność, że wybrane zostaną podmioty, których głównym rodzajem działalności jest produkcja energii z wiatru. Dodatkowym ograniczeniem liczebności próby badawczej było to, że dane finansowe dla bardzo wielu przedsiębiorstw były dostępne jedynie za jeden, dwa lata oraz to, że usuwano niektóre podmioty, których wartość odchylenia standardowego była dwukrotnie wyższa od wartości średniej. W tabeli 2 przedstawiono faktyczną liczbę dostępnych sprawozdań finansowych dla każdego kraju i dla każdego roku objętego badaniem. Przedsiębiorstwa były wybierane losowo, i aby znaleźć się $\mathrm{w}$ próbie badawczej musiały być samodzielnymi jednostkami prowadzącymi pełną rachunkowość (aby były dostępne ich sprawozdania finansowe) z siedzibą w danym kraju. Niestety, liczba dostępnych sprawozdań finansowych nie była wystarczająca, aby ją uznać za statystycznie reprezentatywną dla danego kraju (im mniejsza jest liczebność całej populacji, tym większa musi być $\mathrm{w}$ relacji do niej próba badawcza, aby była reprezentatywna). Dlatego uzyskane wyniki badań należy traktować ostrożnie jedynie jako szacunek sytuacji farm wiatrowych $\mathrm{w}$ danym kraju. Jeżeli jednak przyjąć, że osobne sprawozdania finansowe sporządzają farmy wiatrowe posiadające ponad 5 turbin wiatrowych, wtedy reprezentatywną próbę badawczą udało się uzyskać dla 18 krajów z grupy 25 poddanych badaniu.

Jak wynika $\mathrm{z}$ danych przedstawionych $\mathrm{w}$ tabeli 2 , w każdym z badanych lat populacja przedsiębiorstw była inna, a dane dla krajów, dla których nie znaleziono próby reprezentatywnej, można traktować jedynie jako wartości orientacyjne.

\section{Wyniki badań}

W tabelach 3, 5 oraz 6 przedstawiono (odpowiednio) średnie wartości wskaźników rentowności kapitału własnego, płynności bieżącej oraz zadłużenia odsetkowego do kapitału własnego. $\mathrm{W}$ tabeli 4 przedstawiono procent badanych przedsiębiorstw, który w danym roku wykazał stratę finansową netto.

Tabela 3. Średni wskaźnik rentowności kapitału własnego obliczony dla farm wiatrowych objętych badaniem, lata 2009-2017, wybrane kraje Unii Europejskiej* [w \%]

Table 3. Average return on equity calculated for a selected sample of wind farms, years 2009-2017, selected EU countries [in \%]

\begin{tabular}{l|rrrrrrrrr}
\hline \multicolumn{1}{c}{ Kraj } & \multicolumn{1}{c}{2017} & \multicolumn{1}{c}{2016} & \multicolumn{1}{c}{2015} & 2014 & 2013 & 2012 & 2011 & 2010 & 2009 \\
\hline Austria & 8.7 & -1.9 & 4.0 & 4.4 & 6.7 & 21.6 & 12.3 & 0.2 & -3.0 \\
Belgia & 20.0 & 5.8 & -4.9 & 1.7 & 16.5 & 24.7 & -7.4 & -24.5 & 11.6 \\
Bułgaria & 8.1 & 7.0 & 20.7 & -33.0 & -5.8 & 0.2 & -0.9 & 5.5 & 13.4 \\
Chorwacja & 2.4 & 16.4 & -2.0 & 3.8 & -21.8 & -38.8 & -33.7 & -22.8 & -30.9 \\
Czechy & 17.8 & 0.7 & 26.9 & 12.8 & 6.4 & 11.7 & 12.3 & 6.5 & 9.2 \\
Dania & 10.3 & -21.8 & -12.2 & 4.7 & 4.6 & -0.1 & -10.2 & 20.2 & 15.3 \\
Estonia & 11.3 & 11.8 & 9.2 & 10.3 & 6.2 & 25.1 & 9.5 & 7.3 & -22.7 \\
Finlandia & -12.6 & -47.9 & -50.1 & -19.5 & -27.1 & -67.0 & 25.5 & -3.8 & -17.0 \\
Francja & -11.2 & -17.6 & 16.7 & 3.3 & -1.4 & 5.9 & -36.7 & -66.9 & -56.9 \\
Grecja & 13.5 & -5.5 & 8.3 & 3.5 & -5.9 & 6.5 & -6.8 & -20.1 & -34.1 \\
Hiszpania & 3.8 & -5.6 & 1.6 & -3.5 & 5.5 & 2.8 & 9.7 & 2.1 & 7.3 \\
Holandia & -3.0 & 3.2 & 5.0 & -69.0 & -5.0 & 26.6 & 14.5 & -9.0 & -2.0 \\
\hline
\end{tabular}




\begin{tabular}{l|rrrrrrrrr}
\hline \multicolumn{1}{c}{ Kraj } & \multicolumn{1}{c}{2017} & \multicolumn{1}{c}{2016} & \multicolumn{1}{c}{2015} & \multicolumn{1}{c}{2014} & 2013 & 2012 & 2011 & 2010 & 2009 \\
\hline Irlandia & 56.9 & -8.2 & 18.4 & 15.0 & 53.9 & 38.6 & 23.3 & -10.1 & 56.7 \\
Litwa & b.d. & 6.2 & 19.2 & -4.1 & 21.7 & b.d. & -25.7 & 9.1 & b.d. \\
Lotwa & -16.0 & 3.0 & -36.3 & 1.4 & -30.3 & 28.6 & -20.9 & -22.3 & 20.6 \\
Niemcy & 9.3 & 5.6 & 7.6 & -2.3 & 3.9 & -0.4 & 0.2 & -24.1 & -26.4 \\
Polska & -10.1 & -52.3 & -23.9 & -28.9 & -45.3 & -23.2 & -33.1 & -40.3 & -68.9 \\
Portugalia & 25.8 & 24.2 & 24.8 & 23.8 & 27.9 & 40.8 & -14.2 & 20.0 & -7.8 \\
Rumunia & -25.6 & -8.2 & -27.6 & -36.6 & -21.4 & -29.9 & -45.6 & 3.2 & 29.1 \\
Słowacja & 9.7 & 18.0 & 4.9 & 0.2 & 2.2 & 22.1 & 12.5 & b.d. & b.d. \\
Słowenia & -13.6 & -16.8 & -21.9 & 14.1 & 37.1 & -3.7 & -50.8 & -2.0 & b.d. \\
Szwecja & -28.4 & -38.9 & -20.6 & -29.6 & -33.1 & -31.8 & -5.1 & -7.9 & -11.2 \\
Węgry & -3.8 & -13.1 & -24.0 & -31.2 & 5.5 & 30.2 & -27.7 & -5.8 & -69.7 \\
Wielka Brytania & 27.5 & 8.4 & 54.8 & 16.2 & 23.0 & 9.7 & 20.1 & 5.9 & 9.5 \\
Włochy & -9.7 & -12.0 & -37.0 & -19.7 & -25.3 & -22.4 & -41.1 & -45.0 & -51.8 \\
Razem & -3.0 & -15.0 & -3.7 & -9.1 & -9.6 & -6.4 & -16.8 & -25.6 & -27.7 \\
\hline
\end{tabular}

Źródło: opracowanie własne na podstawie danych z bazy Orbis van der Vijk (* pominięto kraje, dla których nie posiadano danych).

Tabela 4. Udział farm wiatrowych, które wykazały w danym roku obrotowym stratę netto (w \%)

Table 4. Wind farms with net financial losses as a percentage of total wind farms under research, years 2009-2017 [\%]

\begin{tabular}{|c|c|c|c|c|c|c|c|c|c|}
\hline Kraj & 2017 & 2016 & 2015 & 2014 & 2013 & 2012 & 2011 & 2010 & 2009 \\
\hline Austria & 0 & 33 & 13 & 25 & 0 & 0 & 0 & 25 & 100 \\
\hline Belgia & 17 & 29 & 23 & 34 & 29 & 22 & 20 & 50 & 24 \\
\hline Bułgaria & 10 & 4 & 18 & 45 & 36 & 32 & 57 & 20 & 20 \\
\hline Chorwacja & 46 & 36 & 30 & 40 & 67 & 38 & 83 & 67 & 75 \\
\hline Czechy & 0 & 11 & 22 & 25 & 22 & 22 & 22 & 22 & 43 \\
\hline Dania & 31 & 49 & 43 & 41 & 42 & 38 & 44 & 28 & 45 \\
\hline Estonia & 27 & 57 & 29 & 33 & 50 & 30 & 55 & 64 & 67 \\
\hline Finlandia & 52 & 54 & 50 & 49 & 41 & 43 & 41 & 27 & 15 \\
\hline Francja & 50 & 59 & 44 & 47 & 48 & 49 & 67 & 81 & 82 \\
\hline Grecja & 33 & 55 & 38 & 42 & 56 & 43 & 27 & 59 & 47 \\
\hline Hiszpania & 45 & 52 & 42 & 58 & 40 & 35 & 38 & 46 & 50 \\
\hline Holandia & 100 & 33 & 44 & 36 & 23 & 0 & 8 & 50 & 7 \\
\hline Irlandia & 15 & 55 & 36 & 36 & 25 & 29 & 14 & 43 & 36 \\
\hline Litwa & b.d. & 0 & 0 & 33 & 0 & b.d. & 100 & 0 & b.d. \\
\hline Łotwa & 55 & 55 & 55 & 52 & 47 & 48 & 52 & 38 & 33 \\
\hline Niemcy & 29 & 41 & 30 & 54 & 47 & 49 & 45 & 68 & 66 \\
\hline Polska & 59 & 78 & 67 & 73 & 79 & 75 & 82 & 77 & 86 \\
\hline Portugalia & 26 & 24 & 23 & 26 & 22 & 15 & 29 & 37 & 41 \\
\hline Rumunia & 67 & 62 & 55 & 52 & 53 & 49 & 62 & 53 & 31 \\
\hline Słowacja & 0 & 0 & 0 & 0 & 0 & 0 & 0 & b.d. & b.d. \\
\hline Słowenia & 50 & 67 & 100 & 50 & 50 & 100 & 100 & 100 & b.d. \\
\hline Szwecja & 72 & 77 & 60 & 61 & 60 & 54 & 41 & 42 & 37 \\
\hline Węgry & 49 & 52 & 50 & 56 & 38 & 62 & 70 & 58 & 86 \\
\hline Wielka Brytania & 17 & 29 & 16 & 26 & 20 & 25 & 24 & 30 & 24 \\
\hline Włochy & 42 & 55 & 66 & 67 & 69 & 71 & 73 & 81 & 80 \\
\hline Razem & 44 & 54 & 46 & 52 & 50 & 49 & 53 & 60 & 60 \\
\hline
\end{tabular}

Źródło: opracowanie własne na podstawie danych z bazy Orbis van der Vijk (* pominięto kraje, dla których nie posiadano danych). 
Jak wynika $z$ danych przedstawionych w tabelach 3 i 4, straty finansowe netto można było zaobserwować dość regularnie w krajach takich jak: Chorwacja, Finlandia, Francja, Łotwa, Polska, Rumunia, Słowenia, Szwecja, Wegry, Włochy. W Chorwacji, Estonii, Finlandii, Francji, Polsce, Rumunii, Słowenii, Szwecji, Węgrzech i we Włoszech odsetek przedsiębiorstw ze stratą netto regularnie przekraczał dla badanych przedsiębiorstw $50 \%$. Nawet przyjmując duży margines błędu, wynikający z małej liczebności próby badawczej, wyniki te sugerują, że w wymienionych krajach znaczna część farm wiatrowych ponosiła straty. O ile dla części krajów można winić tzw. klimat polityczny, to w wielu przypadkach (Estonia, Chorwacja, Finlandia, Francja, Słowenia, Szwecja) nie ma do tego podstaw, a jednak mimo tego farmy wiatrowe ponoszą straty finansowe. Jak zatem się wydaje, w wielu krajach generowanie zysków z farmy wiatrowej nie jest możliwe, nawet na poziomie zysków netto, bez analizowania zwrotu nakładów inwestycyjnych. Z drugiej strony istnieją kraje, w których stosunkowo wysoki odsetek farm wiatrowych przynosi zyski. Należą do nich: Austria, Belgia, Czechy, Portugalia, Wielka Brytania. Produkcja tej energii w Czechach jest jednak minimalna, więc Czechy można z tej listy pominaćc.

Tabela 5. Średnie wartości wskaźnika płynności bieżącej w latach 2009-2017, w wybranych krajach Unii Europejskiej

Table 5. Average value of current liquidity ratio, years 2009-2017, selected European Union countries

\begin{tabular}{|c|c|c|c|c|c|c|c|c|c|}
\hline Kraj & 2017 & 2016 & 2015 & 2014 & 2013 & 2012 & 2011 & 2010 & 2009 \\
\hline Austria & 0.8 & 26.8 & 59.9 & 18.4 & 27.5 & 23.4 & 38.1 & 31.0 & 0.1 \\
\hline Belgia & 2.5 & 1.8 & 1.9 & 1.8 & 4.1 & 2.2 & 2.5 & 4.3 & 1.8 \\
\hline Bułgaria & 2.5 & 2.8 & 2.0 & 1.4 & 1.8 & 4.8 & 4.9 & 0.9 & 1.4 \\
\hline Chorwacja & 1.4 & 2.1 & 2.5 & 1.3 & 1.1 & 1.9 & 3.5 & 4.7 & 15.9 \\
\hline Czechy & 6.1 & 16.9 & 11.6 & 6.5 & 4.6 & 7.5 & 4.9 & 2.2 & 3.4 \\
\hline Dania & 4.2 & 4.6 & 4.4 & 5.4 & 6.1 & 13.0 & 6.5 & 3.9 & 10.9 \\
\hline Estonia & 0.6 & 0.4 & 0.6 & 0.5 & 1.4 & 0.4 & 0.4 & 2.5 & 2.6 \\
\hline Finlandia & 4.2 & 3.5 & 2.7 & 2.9 & 4.7 & 5.3 & 5.3 & 10.6 & 10.4 \\
\hline Francja & 4.3 & 4.2 & 3.3 & 3.3 & 2.6 & 3.3 & 3.0 & 3.8 & 3.9 \\
\hline Grecja & 5.2 & 7.2 & 2.7 & 6.1 & 4.5 & 4.2 & 7.8 & 6.7 & 6.9 \\
\hline Hiszpania & 2.9 & 2.8 & 4.9 & 2.6 & 2.1 & 2.3 & 2.8 & 3.4 & 3.1 \\
\hline Holandia & 18.9 & 16.0 & 11.1 & 3.1 & 5.3 & 4.6 & 5.2 & 2.2 & 5.3 \\
\hline Irlandia & 2.2 & 1.6 & 1.5 & 1.3 & 0.9 & 1.1 & 1.1 & 4.9 & 3.9 \\
\hline Litwa & b.d. & 0.8 & 0.9 & 1.4 & 0.7 & b.d. & 0.5 & 0.2 & b.d. \\
\hline Łotwa & 9.3 & 13.4 & 7.3 & 12.0 & 9.1 & 19.6 & 18.4 & 9.9 & 5.3 \\
\hline Niemcy & 3.8 & 3.8 & 5.1 & 4.0 & 5.1 & 4.0 & 4.7 & 4.7 & 4.1 \\
\hline Polska & 4.8 & 2.8 & 5.6 & 6.1 & 5.6 & 7.8 & 7.0 & 5.4 & 7.1 \\
\hline Portugalia & 2.5 & 5.7 & 2.2 & 4.1 & 1.6 & 2.5 & 1.7 & 2.1 & 2.4 \\
\hline Rumunia & b.d. & 6.9 & 6.4 & 5.6 & 6.7 & 3.6 & 4.2 & 7.1 & 4.6 \\
\hline Słowacja & b.d. & 19.6 & 8.3 & 7.4 & 6.4 & 15.1 & 22.5 & b.d. & b.d. \\
\hline Słowenia & 0.5 & 9.9 & 0.4 & 0.3 & 1.0 & 1.3 & 0.1 & 24.5 & b.d. \\
\hline Szwecja & 3.3 & 4.2 & 3.5 & 3.4 & 3.3 & 4.3 & 3.7 & 4.0 & 4.4 \\
\hline Węgry & 8.2 & 8.7 & 11.2 & 6.5 & 5.5 & 11.5 & 7.3 & 5.5 & 1.7 \\
\hline Wielka Brytania & 3.9 & 3.4 & 3.4 & 4.1 & 3.7 & 3.3 & 3.4 & 3.2 & 2.3 \\
\hline Włochy & 5.1 & 3.4 & 4.1 & 4.4 & 4.0 & 3.1 & 4.1 & 4.3 & 3.5 \\
\hline Razem & 4.1 & 4.2 & 4.1 & 4.0 & 3.8 & 4.1 & 4.0 & 4.2 & 3.8 \\
\hline
\end{tabular}

Źródło: opracowanie własne na podstawie danych z bazy Orbis van der Vijk (* pominięto kraje, dla których nie posiadano danych). 


\section{J. Wyrobek}

W tabeli 5 przedstawiono średnią wartość wskaźnika płynności bieżącej dla badanych krajów. Wartości wskaźnika dla Austrii wskazują na nadpłynność, a dla Estonii, Litwy i Słowenii na potencjalne problemy z utrzymaniem płynności finansowej. Dla pozostałych krajów wskaźniki płynności utrzymywały się na stabilnym poziomie.

W tabeli 6 zaprezentowano średnie wartości wskaźnika zadłużenia mierzonego jako relacja zobowiązań odsetkowych do kapitału własnego. Wartość tego wskaźnika na poziomie 1:1 jest uważana za odpowiednią, natomiast wyższy poziom może sygnalizować nadmierne finansowanie długiem (choć warto sprawdzić wskaźnik pokrycia odsetek, bo nie zawsze wyższe zadłużenie jest niebezpieczne dla przedsiębiorstwa). Przedstawione w tabeli 6 liczby znacząco przekraczają tę wartość, ale może o tym decydować specyfika branży, która wymaga wysokich nakładów inwestycyjnych na początku projektu. Pocieszające jest to, że wskaźniki zadłużenia nie rosną w czasie, można zaobserwować ich powolny spadek. Sugeruje to, że zadłużenie farm wiatrowych nie ma tendencji do wzrostu w czasie, jednakże jest ogólnie dla branży bardzo wysokie.

Tabela 6. Średnia wartość wskaźnika zobowiązania odsetkowe do kapitału własnego dla farm wiatrowych w wybranych krajach UE*, lata 2009-2017, wybrane kraje Unii Europejskiej* [w \%]

Table 6. Average financial gearing ratio for wind farms in selected EU countries*, years 2009-2017 [in \%]

\begin{tabular}{|c|c|c|c|c|c|c|c|c|c|}
\hline Kraj & 2017 & 2016 & 2015 & 2014 & 2013 & 2012 & 2011 & 2010 & 2009 \\
\hline Austria & 137 & 105 & 147 & 130 & 134 & 371 & 256 & 280 & 377 \\
\hline Belgia & 212 & 205 & 178 & 212 & 229 & 261 & 243 & 223 & 199 \\
\hline Bułgaria & 156 & 153 & 135 & 153 & 207 & 187 & 184 & 302 & 279 \\
\hline Chorwacja & 252 & 257 & 271 & 212 & 138 & 74 & 115 & 242 & 170 \\
\hline Czechy & 170 & 149 & 102 & 206 & 249 & 233 & 266 & 330 & 226 \\
\hline Dania & 127 & 126 & 131 & 114 & 133 & 19 & 42 & 39 & 17 \\
\hline Estonia & 156 & 148 & 226 & 284 & 166 & 110 & 131 & 294 & 282 \\
\hline Finlandia & 184 & 173 & 227 & 169 & 210 & 347 & 155 & 169 & 182 \\
\hline Francja & 156 & 172 & 197 & 159 & 171 & 149 & 139 & 120 & 107 \\
\hline Grecja & 266 & 52 & 107 & 56 & 83 & 91 & 117 & 100 & 49 \\
\hline Hiszpania & 157 & 206 & 223 & 208 & 214 & 197 & 227 & 193 & 187 \\
\hline Holandia & b.d. & 96 & 9 & 97 & 50 & 49 & 40 & 98 & 89 \\
\hline Irlandia & 315 & 343 & 313 & 282 & 252 & 301 & 288 & 238 & 163 \\
\hline Litwa & b.d. & b.d. & 323 & 496 & 700 & b.d. & b.d. & b.d. & b.d. \\
\hline Łotwa & 87 & 10 & 16 & 33 & 41 & 42 & 32 & 114 & 27 \\
\hline Niemcy & 250 & 255 & 281 & 278 & 305 & 317 & 250 & 260 & 258 \\
\hline Polska & 206 & 188 & 160 & 156 & 163 & 134 & 204 & 159 & 104 \\
\hline Portugalia & 216 & 241 & 238 & 222 & 323 & 280 & 303 & 324 & 249 \\
\hline Rumunia & b.d. & 111 & 37 & 73 & b.d. & b.d. & b.d. & b.d. & b.d. \\
\hline Słowacja & 0 & 0 & 10 & 13 & 16 & b.d. & b.d. & b.d. & b.d. \\
\hline Słowenia & 8 & 555 & 458 & 346 & 346 & 346 & b.d. & b.d. & b.d. \\
\hline Szwecja & 145 & 143 & 150 & 154 & 182 & 191 & 225 & 188 & 146 \\
\hline Węgry & 86 & 95 & 57 & 24 & 52 & 88 & 71 & 69 & 41 \\
\hline Wielka Brytania & 189 & 177 & 187 & 188 & 223 & 206 & 214 & 190 & 197 \\
\hline Włochy & 136 & 138 & 139 & 126 & 101 & 100 & 89 & 69 & 53 \\
\hline Razem & 160 & 170 & 178 & 165 & 181 & 173 & 172 & 155 & 137 \\
\hline
\end{tabular}

Źródło: opracowanie własne na podstawie danych z bazy Orbis van der Vijk (*pominięto kraje, dla których nie posiadano danych). 


\section{Wnioski i rekomendacje}

Podsumowując rozważania zawarte $\mathrm{w}$ pracy wydaje się, że trudno $\mathrm{z}$ poziomu sprawozdań finansowych określić efektywność finansową farm wiatrowych jako zadawalająca. Nie oznacza to, że inwestycje w energetykę wiatrową muszą prowadzić do strat. Być może sprawozdania nie oddają całej rzeczywistości, bądź też potrzeba czasu, aby inwestycje tego typu zaczęły przynosić częściej zyski. Badania wykazały też, że nie ma szczególnie silnych powiązań pomiędzy rentownością farm wiatrowych a pozytywna, neutralną czy negatywną atmosferą polityczną wobec energii wiatrowej. Najbardziej rentowna produkcja energii z wiatru wydaje się być w Austrii, Belgii, Portugalii i Wielkiej Brytanii. Wskazują na to wyniki analizy sprawozdań finansowych.

Dobre wyniki farm wiatrowych we wspomnianych krajach pokrywają się z relatywnie wysokimi cenami energii elektrycznej, jakie obowiązują w tych krajach. Jedynie Niemcy są wyjątkiem, w którym obowiązują wysokie ceny energii elektrycznej, a jednocześnie duża część farm wiatrowych ponosi straty (działa tam jednak rekordowa liczba elektrowni wiatrowych, duża częśc $\mathrm{z}$ nich to małe firmy rodzinne). Poza tym wyjątkiem, we wszystkich innych badanych krajach można zauważyć wyraźną zależność pomiędzy wynikami farm wiatrowych a cenami energii.

Tabela 7. Średnia cena energii elektrycznej dla gospodarstw domowych w latach 2010-2017 w wybranych krajach Unii Europejskiej, cena w euro za 100 MWh (ze wszystkimi opłatami i podatkami)

Table 7. Average price of electricity for households in years 2010-2017 in selected EU countries [euro/100 MWh]

\begin{tabular}{|c|c|c|c|c|c|c|c|c|}
\hline Kraj & 2017 & 2016 & 2015 & 2014 & 2013 & 2012 & 2011 & 2010 \\
\hline Austria & 20 & 20 & 20 & 20 & 20 & 20 & 20 & 19 \\
\hline Belgia & 28 & 27 & 24 & 20 & 22 & 22 & 21 & 20 \\
\hline Bułgaria & 10 & 10 & 9 & 9 & 9 & 10 & 9 & 8 \\
\hline Chorwacja & 12 & 13 & 13 & 13 & 14 & 14 & 11 & 12 \\
\hline Czechy & 14 & 14 & 14 & 13 & 15 & 15 & 15 & 14 \\
\hline Dania & 30 & 31 & 30 & 30 & 29 & 30 & 30 & 27 \\
\hline Estonia & 12 & 12 & 13 & 13 & 14 & 11 & 10 & 10 \\
\hline Finlandia & 16 & 15 & 15 & 15 & 16 & 16 & 16 & 14 \\
\hline Francja & 17 & 17 & 17 & 18 & 16 & 15 & 14 & 14 \\
\hline Grecja & 19 & 17 & 18 & 18 & 16 & 14 & 12 & 12 \\
\hline Hiszpania & 23 & 23 & 24 & 24 & 23 & 23 & 21 & 19 \\
\hline Holandia & 16 & 16 & 18 & 17 & 19 & 19 & 18 & 18 \\
\hline Irlandia & 23 & 23 & 25 & 25 & 24 & 23 & 21 & 19 \\
\hline Litwa & 11 & 12 & 12 & 13 & 14 & 13 & 12 & 12 \\
\hline Łotwa & 16 & b.d. & b.d. & 13 & 14 & 14 & 13 & 10 \\
\hline Niemcy & 30 & 30 & 29 & 30 & 29 & 27 & 25 & 24 \\
\hline Polska & 15 & 14 & 14 & 14 & 14 & 15 & 14 & 14 \\
\hline Portugalia & 23 & 24 & 23 & 22 & 21 & 21 & 19 & 17 \\
\hline Rumunia & 12 & 12 & 13 & 12 & 13 & 11 & 11 & 11 \\
\hline Słowacja & 14 & 15 & 15 & 15 & 17 & 17 & 17 & 16 \\
\hline Szwecja & 19 & 20 & 19 & 19 & 20 & 21 & 20 & 20 \\
\hline Węgry & 11 & 11 & 11 & 11 & 13 & 16 & 16 & 16 \\
\hline Wielka Brytania & 18 & 18 & 22 & 20 & 18 & 18 & 16 & 14 \\
\hline Włochy & 21 & 23 & 24 & 23 & 23 & 23 & 21 & 19 \\
\hline
\end{tabular}

Źródło: opracowanie własne na podstawie danych z bazy Eurostat. 


\section{J. Wyrobek}

Rentowność farm wiatrowych w dużym stopniu zależy od cen energii, czyli tego, co farmy tworzą i sprzedają (tabela 7). Wciąż też pomiędzy Europą Zachodnią a ŚrodkowoWschodnią występują różnice w poziomie cen, co przekłada się na rentowność farm wiatrowych. Najlepsze wyniki farmy wiatrowe uzyskują bowiem w Europe Zachodniej. Jednakże również w krajach Europy Środkowo-Centralnej część elektrowni wiatrowych generuje zyski, mimo że ceny energii stanowią $1 / 2$ lub nawet $1 / 3$ cen z krajów Europy Zachodniej. Wydaje się zatem, że energetyka wiatrowa w tych krajach wymaga dużo staranniejszego namysłu i kontroli, aby była rentowna przy niższym poziomie cen. Farmy wiatrowe, które regularnie realizują zyski w takich krajach powinny być badane pod kątem czynników sukcesu pozwalających im, mimo trudnych warunków, utrzymać rentowność.

\section{Literatura}

Bruck, M., Sandborn, P., Goudarzi, N. (2018). A levelized cost of energy (LCOE) model for wind farms that include power purchase agreements (PPAs). Renewable Energy, 122, 131-139.

Fraunhofer ISE, Studie (2018). Stromgestehungskosten erneuerbare Energien - Marz 2018. Pobrano 11.12.2018 r. z: https://www.ise.fraunhofer.de/de/veroeffentlichungen/studien/studie-stromgestehungskosten-erneuerbareenergien.html.

Gielnik, A., Rosicki, R. (2013). Energetyka wiatrowa w Polsce - możliwości rozwoju i zagrożenia. W: Kwiatkiewicz P., Bezpieczeństwo energetyczne - surowce kopalne vs alternatywne źródła energii, WSB, Poznań, 191-205.

Gnatowska, R., Wąs, A. (2015). Analiza opłacalności inwestycji w produkcję energii ze źródeł odnawialnych na przykładzie farmy wiatrowej przy założeniu wsparcia rządu dla „zielonej energii”. Inżynieria $i$ Ochrona Środowiska, 18(1), 23-33

Mielcarek, J. (2014). Analiza projektu farmy wiatrowej za pomocą rachunku kosztów docelowych. Prace Naukowe Uniwersytetu Ekonomicznego we Wrocławiu, 365, 155-173.

Nuclear Energy Agency / International Energy Agency/Organization for Economic Cooperation and Development. (2015). Projected Costs of Generating Electricity.

Wieczerzak-Krusińska, A. (2018). Wysokie ceny prądu z węgla, Energetyka, 29.09.2018. Parkiet. Pobrano 11.12.2018 r. z: https://www.parkiet.com/Energetyka/309299975-Wysokie-ceny-pradu-z-wegla.html.

Do cytowania / For citation:

Wyrobek J. (2018). Analiza porównawcza sytuacji finansowej farm wiatrowych w wybranych krajach Unii Europejskiej w latach 2009-2017. Problemy Rolnictwa Światowego, 18(4), 504-514;

DOI: $10.22630 /$ PRS.2018.18.4.138

Wyrobek J. (2018). Comparative Analysis of Wind Farms Financial Situation in Selected Countries of the European Union in years 2009-2017 (in Polish). Problems of World Agriculture, 18(4), 504-514; DOI: 10.22630/PRS.2018.18.4.138 